\title{
Influence of storage on the physical and chemical properties of Scots pine bark
}

\author{
Johanna Routa ${ }^{1}$ (D) $\cdot$ Hanna Brännström ${ }^{2} \cdot$ Jarkko Hellström $^{3} \cdot$ Juha Laitila $^{1}$
}

Received: 30 March 2020 / Accepted: 15 October 2020 / Published online: 28 October 2020

(C) The Author(s) 2020

\begin{abstract}
Bark is currently used mainly to produce energy, but the extraction of valuable compounds before combustion offers an interesting cascading use for debarking biomass. Buffer storage is an inevitable part of bark biomass logistics, but substantial dry matter and extractive losses can degrade the properties and reduce the economic value of the raw material during storage. In this study, moisture and ash content, calorific value, and extractives content and composition of Scots pine (Pinus sylvestris) sawmill bark were determined over 2 months of buffer storage, and the change in energy content during storage was calculated. The results showed that the energy content $\left(\mathrm{MWh} \mathrm{m}^{-3}\right)$ of the bark increased 3\% during storage, while at the same time the moisture content decreased $16 \%$. The content of acetone-soluble extractives decreased markedly, with only $56 \%$ of the original amount remaining after 8 weeks of storage. In particular, hydrophilic, phenolic extractive compounds were rapidly lost after debarking and piling of the bark. About $60 \%$ of condensed tannins (CT) and about $26 \%$ of the quantified lipophilic compounds were lost after 2 weeks of storage. The fastest rate of decrease and the most significant changes in extractives content and composition occurred within the first 2 weeks of storage. Utilization of these valuable compounds necessitates fast supply of material for further processing after debarking. The comprehensive utilization of bark requires efficiency at all levels of the supply chain to ensure that tree delivery times are kept short and loss of bark is avoided during harvest and transport.
\end{abstract}

Keywords Bark $\cdot$ Pinus sylvestris $\cdot$ Moisture $\cdot$ Energy content $\cdot$ Extractives $\cdot$ Debarking

\section{Introduction}

EU-wide environmental targets and policy objectives for the period from 2021 to 2030 are presented in the 2030 Climate and Energy Framework. One of the key targets is achieving at least a $32 \%$ renewable share of energy in the EU [1]. The share of renewable fuels in the Finnish national energy supply was set to be increased to $38 \%$ of total energy consumption by

Supplementary Information The online version contains supplementary material available at https://doi.org/10.1007/s12155-02010206-8.

Johanna Routa

johanna.routa@luke.fi

1 Forest Technology and Logistics, Natural Resources Institute Finland, Yliopistokatu 6B, 80101 Joensuu, Finland

2 Biorefinery and bioproducts, Natural Resources Institute Finland, Teknologiakatu 7, 67100 Kokkola, Finland

3 Food processing and quality, Natural Resources Institute Finland Myllytie 1, 31600 Jokioinen, Finland
2020 [2], and this goal was actually achieved in 2014 [3]. The success was achieved mainly by increasing the use of various types of biomass, especially forest chips and forest industry by-products, in energy generation. According to the latest statistics [4], the main solid wood fuel used in heat and power production was bark, with 7.7 million $\mathrm{m}^{3}(47.5 \mathrm{TJ})$ in 2018. Bark is a by-product from the sawmill and pulp industry. As the Finnish milling and pulp industry processes mainly coniferous wood, debarking residues from coniferous trees are the most common bark used as fuel.

The debarking of logs is usually the first processing stage in the mechanical and chemical forest industry. The aim of debarking is to avoid many harmful effects in subsequent process stages [5].

The pulp industry and sawmills use different debarking technologies. In the debarking drum, pulpwood logs are tumbled against each other to remove the bark, and the process is driven by a low amount of water or steam. Cutting season, temperature, and the quality of the raw material, i.e. species, $\log$ freshness, and log dimensions, affect the wood loss in the debarking drum. Koskinen [6] and Agin and Svensson [7] reported that the wood loss in the debarking drum varied 
between 1 and $6 \%$. The end product, especially in chemical and mechanical pulping, mainly determines the requirements for bark removal, which is measured by the log cleanliness measurement system. Log cleanliness is defined as the percentage of the log surface that is free of bark after debarking [8]. The debarking result is a compromise between wood loss and bark removal.

Rotary debarking is the preferred method in the sawmill and veneer industries. The logs of the primary wood product industries are debarked, because processing residues (chips) are commonly used as a raw material in chemical and mechanical pulping.

The value chain of forest biomass for energy always includes biomass storage [9]. As supply volumes and commercial values have increased, the economic losses associated with the poor storage management of biomass have become obvious. The energy yields per unit of delivered biomass can be maximized, and emissions can be minimized, through the careful establishment and location of the storage, prediction and measurement of the changing moisture content, and the ability to match supply with demand [9]. Storage of bark has been overlooked in the scientific literature to date [10]. Research has focused on studying stem wood, wood chips, and forest residues.

The content of extractives in Scots pine (Pinus sylvestris L.) bark is generally between 16 and 25.9 as a percentage of dry matter (d.m.), whereas the extractives content in P. sylvestris stem wood is usually between 1 and $6.8 \%$ (d.m.) [11-14]. This makes pine bark an attractive raw material for biorefining. There are large volumes of potentially available Scots pine (P. sylvestris) bark, as it is one of the main softwood species in Fennoscandia [15]. Currently, pine bark is commonly used to produce heat at mills or power plants.

Scots pine bark has an attractive chemical composition for the production of high-value biochemicals. Miranda et al. [16] reported hydrophilic extractives content of $14.4 \%$ in pine bark (d.m.). This group of extractives includes valuable phenolic compounds. For example, Scots pine bark contains relatively high content of condensed tannins, between 3.2 and $8.5 \%$ (d.m.), which have applications in adhesives, rigid insulating foams, as flocculants in wastewater treatment, and in pharmaceuticals, food supplements, animal feeds, and cosmetics [17-21]. In addition, the content of lipophilic compounds in Scots pine bark is high, between 4.4 and $7.3 \%$ (d.m.) [16, 22], and these lipophilic compounds also have potential high-value applications as epoxy resins, surfactants, defoaming agents, emulsifiers, soaps, paper sizing agents, printing ink resins, cosmetics, and many others [23-25].

Major changes to woody biomass during storage are caused by three key mechanisms: (1) living cell respiration, (2) biological degradation, and (3) thermo-chemical oxidative reactions [10]. The microbial activity in storage piles, along with other factors including biological and chemical processes and moisture levels within the stack, causes problems such as heat buildup, biomass loss, and degraded fuel quality. Dry matter loss (DML) of between 0.4 and $10.2 \%$ per month has been observed in stored bark [26-29]. The biological processes can lead to various chemical processes that occur at higher temperatures. In large biomass piles, self-heating can be a hazard, when the internal temperature of the pile increases over time and self-ignition occurs [30].

Many of the potentially valuable extractive compounds are either rather volatile or chemically unstable. The extractives content starts to decrease immediately after tree felling, and this degradation continues throughout the supply chain [31-34]. As a result, the chemical composition of the extractive-based fraction also changes over time.

The major reactions of lipophilic extractive compounds during wood storage can be divided into three types: (1) hydrolysis of triglycerides (rapid reaction) and steryl esters and waxes (proceeds slower); (2) oxidation/degradation/polymerization of resin acids, unsaturated fatty acids, and - to some extent - other unsaturated compounds; and (3) evaporation of volatile terpenoids, mainly monoterpenes [33]. Phenolic extractives are hydrophilic by nature. Thus, in addition to microbial and chemical degradation reactions, they are also lost due to leaching. Phenolic compounds may also experience photodegradation during storage, through the formation of phenoxy radicals facilitated by UV light exposure and enzymatic activity $[35,36]$. Phenoxy radicals are highly unstable and may lead to polymerization or cyclization reactions [37]. High temperatures in piles can also lead to the thermal decomposition of some of the chemical components of bark [30]. Some compounds are released in the form of gaseous organic pollutants (volatile organic compounds, VOC), and some compounds are released via leachate.

Increasing the value of bark for bioenergy and as a raw material for biorefineries is the key issue in this study. The aim of the study was to determine the changes in quality of Scots pine sawmill bark during storage. In addition, the amount of extractives was measured after 2,4 , and 8 weeks of storage to monitor the changes in the chemical composition of the bark.

\section{Materials and methods}

\section{Experimental design}

The storage experiment was conducted in Uimaharju $\left(62^{\circ} 54^{\prime}\right.$ N, 30 $0^{\circ} 14^{\prime}$ E), Eastern Finland, at a sawmill storage site and was carried out from August 22, 2018, to October 18, 2018. One pile of fresh pine (Pinus sylvestris) sawlog bark was established at the Uimaharju sawmill. The accumulated 
rainfall for the 2-month follow-up period was $158 \mathrm{~mm}$, and the mean air temperature was $10.1 \mathrm{C}^{\circ}$.

Sawlogs were harvested by a harvester around 2 weeks before storage. Fresh wood was debarked with a Valon Kone VK-820 rotary debarking machine on the same day the pile was established. The bark was piled with a wheel loader. The size of the pile was $16.4 \times 6.2 \times 3 \mathrm{~m}$ (length, width, height). The pine bark contained a large amount of stem wood; the average share of wood pieces in samples in this study was $20 \%$.

Sampling was carried out with balance bags. The samples were individually mixed to homogeneity and divided into two subsamples of about equal weight (1000 g). The first subsample was packed in a plastic bag and set aside for measurement of pre-storage wet-basis moisture content and basic density. The other subsample was packed in a polyester bag $(40 \times 50$ $\mathrm{cm})$ with a $1-\mathrm{mm}$ oval mesh. The bark for the balance bags was thoroughly homogenized to ensure the same starting conditions for all samples within one pile and to achieve minimal variance in the initial data. In constructing the experiment, the balance bags were arranged grid-wise within the piles. A total of 30 balance bags were placed in the pile at three different levels. The first level (bottom), with 11 bags, was at a height of $0.5 \mathrm{~m}$ from the ground, the second (middle) was $1.3 \mathrm{~m}$ (11 bags), and the third (top) was $2 \mathrm{~m}$ ( 8 bags).

Samples for chemical analyses were collected from different truckloads, and combined and mixed. A sample of approximately $5 \mathrm{~L}$ was placed in the sampling bag. Three larger samples were also collected, which were further divided into subsamples at the laboratory.

During the storage period, the bags were extracted after 2, 4 , and 8 weeks, using a drag rope and wheel loader/excavator. After 2 weeks, eight bags were removed from the pile, all from the same cross-section, and after 4 weeks, eight bags were removed from another cross-section. At the end of the experiment, the other 14 bags were removed. Samples for determining the extractives amount were taken at the same time and from the same places as the balance bags. The sample for extraction was packed in a 5-L plastic bag.

The in-pile temperature was recorded at 1-h time intervals using miniature temperature data loggers (a-Nap, a-Lab Ltd, Keuruu, Finland) and 3-h time intervals using thermo cables. Five a-Nap data loggers and five thermo cables were placed on the pile at different levels. After a 4-week storage period, one thermo cable broke when the samples were taken.

\section{Sampling methods}

The sampling procedure and sampling preparation followed the standard methods valid at the time of the experiments. Moisture content was analyzed according to the Finnish Standards Association SFS-EN 14774-2 standard [38]. Ash content was determined according to SFS-EN 14775 [39]. A method modified from the Scandinavian Pulp, Paper and Board Testing Committee standard SCAN-CM 43:95 [40] was applied to determine the basic density of the bark samples. Calorimetric heating measurements and calculation of the gross calorific values were performed according the European Committee for Standardization CEN/TS 14918:2005 methods [41], using an IKA ${ }^{\circledR} \mathrm{C} 5000$ bomb calorimeter (IKA ${ }^{\circledR}$-Werke GmbH \& Co. KG, Germany).

\section{Calculation of energy content and dry matter losses}

The energy content of the study piles was calculated at the beginning and end of the experiment, based on the measured moisture content. The net calorific value and energy content of the as-received bark were calculated according to the following equations [42]:

$q_{p, n e t, a r}=q_{p, n e t, d} *\left(\frac{100-M_{a r}}{100}\right)-0.02443 * M_{a r}$,

where

$\mathrm{q}_{\mathrm{p}, \text { net,ar }} \quad$ net calorific value as received $\left(\mathrm{MJ} \mathrm{kg}^{-1}\right)$,

$\mathrm{q}_{\mathrm{p}, \text { net,d }} \quad$ net calorific value on a dry basis $\left(\mathrm{MJ} \mathrm{kg}^{-1}\right.$ ),

$\mathrm{M}_{\mathrm{ar}} \quad$ moisture content as received,

0.02443 the correction factor of the enthalpy of vaporization at $25^{\circ} \mathrm{C}$, and

$E_{a r}=\frac{1}{3600} * q_{p, n e t, a r} * B D_{a r}$

where

$\mathrm{E}_{\mathrm{ar}} \quad$ energy content as received $\left(\mathrm{MWh} \mathrm{m}^{-3}\right)$,

$\mathrm{q}_{\mathrm{p}, \text { net,ar }}$ net calorific value as received $\left(\mathrm{MJ} \mathrm{kg}^{-1}\right)$, and

$\mathrm{BD}_{\mathrm{ar}}$ density as received $\left(\mathrm{kg} \mathrm{m}^{-3}\right)$.

The moisture content, basic density, and net calorific values of dry matter measured in the samples from the balance bags at the beginning and end of the experiment were used in the calculation.

\section{Extractives analysis}

Samples were stored in a freezer $\left(<-20^{\circ} \mathrm{C}\right)$. Prior extraction samples were freeze-dried and ground with a Retsch SM 100 laboratory cutting mill (Retsch GmbH, Haan, Germany), equipped with a bottom sieve with trapezoidal holes (perforation size $<1.0 \mathrm{~mm}$ ). The moisture content of the ground samples was determined according to the SFS-EN 14774-3 standard method by drying $1 \mathrm{~g}$ of bark powder at $105^{\circ} \mathrm{C}$ in an oven. The extraction of bark samples was done with a Foss Soxtec ${ }^{\mathrm{TM}} 8000$ unit. The extractions were performed in duplicate. Two grams of bark powder was used for each extraction. 
Samples were extracted with $80 \mathrm{ml}$ acetone in boiling solvent for $15 \mathrm{~min}$, after which the thimble was raised to the rinse position for $60 \mathrm{~min}$. The acetone extracts were first concentrated by extractor, and drying was finalized before weighing using a nitrogen stream. These duplicate samples were further analyzed with gas chromatography (GC).

The methods used for the analysis of extractive compounds were modified from the original methods proposed by Örså and Holmbom [43]. To analyze individual extractive compounds, about $13 \mathrm{mg}$ of bark extract and $200 \mu \mathrm{g}$ of internal standards (heneicosanoic acid and betulin) were derivatized with a mixture of pyridine and 1-(trimethylsilyl)imidazole after drying with nitrogen stream. The derivatization of samples was performed by keeping them at room temperature overnight. GC analysis of the individual compounds was carried out on an Agilent 6890 Series GC system equipped with a 7683 injector and an Agilent 5973 mass selective detector (MSD). The capillary column used was the Zebron ZB-SemiVolatiles $(30 \mathrm{~m} \times 0.25 \mathrm{~mm}$, film thickness $0.25 \mu \mathrm{m})$. The injector temperature was $280^{\circ} \mathrm{C}$, with $1 \mu \mathrm{l}$ injection volume and split injection mode (split ratio 21.6:1). Helium was used as the carrier gas. The initial GC oven temperature was $180{ }^{\circ} \mathrm{C}$, followed by an increase of $5^{\circ} \mathrm{C} / \mathrm{min}$ to $320^{\circ} \mathrm{C}$, and $12 \mathrm{~min}$ at $320^{\circ} \mathrm{C}$.

A quantitative analysis of triglycerides and steryl esters was performed with the same GC system as the analysis of individual compounds. About $3.5 \mathrm{mg}$ of extract and $200 \mu \mathrm{g}$ of internal standards cholesteryl heptadecanoate, heneicosanoic acid, and 1.3-dipalmitoyl-2-oleoylglycerol and $75 \mu \mathrm{g}$ betulin were added to the sample, which was analyzed without derivatization. A short DB-1ht capillary column $(15 \mathrm{~m} \times 0.25 \mathrm{~mm}$, film thickness $0.1 \mathrm{~m}$ ) was used. The injector temperature was $280{ }^{\circ} \mathrm{C}$, with injection volume of $3 \mu \mathrm{l}$ and pulsed splitless injection mode. The initial GC oven temperature was 150 ${ }^{\circ} \mathrm{C}$, followed by an increase of $20^{\circ} \mathrm{C} / \mathrm{min}$ to $350{ }^{\circ} \mathrm{C}$, and 10 min at $3500^{\circ} \mathrm{C}$.

Condensed tannin (CT, proanthocyanidins) content was determined by high-performance liquid chromatography (HPLC) after thiolytic degradation, following Mattila et al. [44]. Briefly, the samples were weighed $(20-30 \mathrm{mg})$ in $1.5 \mathrm{~mL}$ Eppendorf vials, and $1 \mathrm{~mL}$ of depolymerization reagent ( $3 \mathrm{~g}$ cysteamine/4 $\mathrm{mL} 13 \mathrm{M} \mathrm{HCl} / 56 \mathrm{~mL}$ methanol) was added. The vials were sealed and incubated for $60 \mathrm{~min}$ at $65^{\circ} \mathrm{C}$, after which the degradation products, i.e. free flavan-3-ols (terminal units) and their cysteaminyl derivatives (extension units), were separated on a Zorbax Eclipse Plus C18 column $(2.1 \times 50 \mathrm{~mm}, 1.8 \mu \mathrm{m})$ and determined by HPLC (Agilent 1290 Infinity, Agilent Technologies, Inc., Santa Clara, CA, USA), equipped with diode array (DAD) and fluorescence detection (FLD).

\section{Chemicals}

HPLC-grade $(\geq 99.8 \%)$ acetone (VWR Chemicals $\mathrm{BDH}^{\circledR}$ ) was used for extraction. The compounds used as internal standards in the GC analysis of the extractives were heneicosanoic acid (99\%), betulin (98\%), cholesteryl heptadecanoate, and 1.3-dipalmitoyl-2-oleoylglyserol (>99\%), all purchased from Sigma-Aldrich (St. Louis, MO, USA).

The solvents used in the sample preparation of extractives were analytical-grade pyridine $(99.5 \%$, Merck KGaA, Darmstadt, Germany) and 1-(trimethylsilyl)imidazole (96\%, Sigma-Aldrich, St. Louis, MO, USA).

Standard compounds applied for CT analyses were (+)catechin (99\%, Sigma-Aldrich, St. Louis, MO USA), (-)-epicatechin (98\%, Sigma-Aldrich), and procyanidin B2 (>90\%, Extrasynthese, Lyon, France). Cysteamine (98\%) and formic acid (98\%) were obtained from Sigma-Aldrich (St. Louis, MO, USA), and 13M HCl from Fisher Scientific (Waltham, MA, USA). HPLC-grade methanol $(\geq 99.8 \%)$ and acetonitrile $\left(\geq 99.8 \%\right.$ ) were obtained from VWR Chemicals $\mathrm{BDH}^{\circledR}$.

\section{Statistical analyses}

Statistical analyses were performed using IBM SPSS Statistics version 25 software (IBM Corp., Armonk, NY, USA). The significance level was $5 \%(p \leq 0.05)$ for all tests. Analysis of variance (ANOVA) was performed for moisture, ash, extractives, and condensed tannin (CT) content, basic density, and energy content data to identify the differences in the pile. A post hoc test, i.e. a Bonferroni-corrected $t$ test, was conducted for extractives content measurements and the results of the compound group analysis (steryl esters, triglycerides, phenolic extractives, sterols). For free fatty acid, resin acid, and CT content, ANOVA with a Welch test was carried out due to the violation of homogeneity of variance (significant Levene's test). A Games-Howell post hoc test was conducted for these results.

Variation in moisture content was visualized by interpolating a raster surface from sample points, using an inverse distance weighting method.

\section{Results}

\section{Temperature}

After the pile was established, the temperature in the middle of the pine bark stockpile rose rapidly, reaching $60^{\circ} \mathrm{C}$ within 3 days, but then declined rapidly (Fig. 1). After 2 months, the temperature in the pile had decreased to ca. $25^{\circ} \mathrm{C}$. The temperature was highest in the middle and at the top of the pile for the first 3 weeks in undisturbed parts of the bark pile. At the bottom level, the temperature increased less and declined more slowly. The temperature at the top and in the middle of the pile decreased markedly after 3 weeks, with the temperature fluctuating between 8 and $35^{\circ} \mathrm{C}$ at the top of the pile (Fig. 


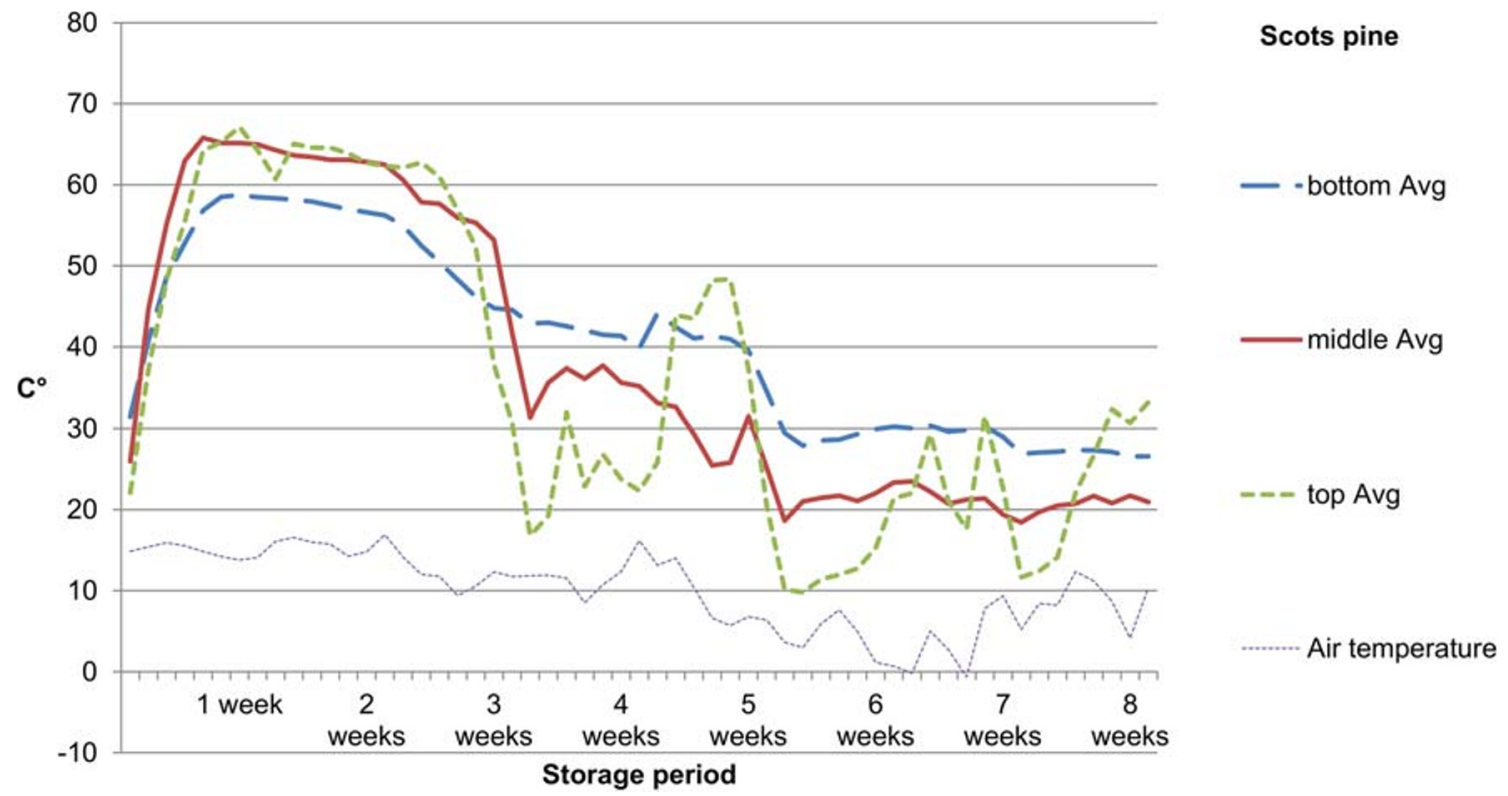

Fig. 1 Temperature development in the pine bark pile at different levels (bottom, middle, and top, undisturbed parts) during the 2-month storage period

1). The disturbance of the pile during sample collection at 2 and 4 weeks caused a brief decrease in the temperature.

\section{Moisture content}

The average initial moisture content of the bark pile was $47.5 \% \pm$ 2.05 (range 43.6-51.7\%), and at the end of experiment it had decreased by $16 \%$ to $31.4 \% \pm 3.92$ (range $25.5-37.7 \%$ ). The lowest moisture content at the end of the experiment was found in the middle of the pile (Fig. 3), but there were no statistically significant differences $(p=0.168)$ between the bottom, middle, and top parts of the pile. The moisture in the middle of the pile did not differ statistically significantly $(p=0.575)$ from the moisture at the edges of the pile (Figs. 2 and 3).

\section{Ash content}

The average ash content of the fresh pine bark was $1.89 \%$ $( \pm 0.06)$ (Table 1). After 8 weeks of storage, the average ash content was $1.97 \%( \pm 0.05)$. The difference was statistically significant $(p=0.00)$. The ash content at the end of the experiment showed no statistically significant differences $(p=$ 0.612 ) at different levels of the pile (bottom, middle, and top).

\section{Basic density}

At the beginning of the experiment, the basic density of the pine bark was $316 \pm 6.2 \mathrm{~kg} \mathrm{~m}^{3}$ (varying between 301 and $329 \mathrm{~kg} \mathrm{~m}^{3}$ ) (Fig. 4). During the 8 weeks, the storage density declined to $309 \pm 5.8 \mathrm{~kg} \mathrm{~m}^{3}(-2.3 \%)$. The change was statistically significant $(p=0.001)$. The density at the end of the experiment showed no statistically significant differences $(p=0.485)$ at the different levels of the pile (bottom, middle, and top).

\section{Energy content and calorific value}

The average net calorific value $\left(\mathrm{q}_{\mathrm{p}, \text { net, } \mathrm{d}}\right)$, of the pine bark was $19.7( \pm 0.13) \mathrm{MJ} \mathrm{kg}^{-1}$, and after 8 weeks of storage it was the same, $19.7( \pm 0.11) \mathrm{MJ} \mathrm{kg}^{-1}$ (Table 1). Correspondingly, the average gross calorific dry basis value $\left(\mathrm{MJ} \mathrm{kg}^{-1}\right)\left(\mathrm{q}_{\mathrm{gr}}\right)$ was $20.99( \pm 0.13) \mathrm{MJ} \mathrm{kg}^{-1}$, and after 8 weeks of storage it was $21.00( \pm 0.11) \mathrm{MJ} \mathrm{kg}^{-1}$. The energy content of the fresh pine bark was $1.54( \pm 0.03) \mathrm{MWh}$ $\mathrm{m}^{-3}$, and during storage it increased slowly to 1.59 $( \pm 0.027) \mathrm{MWh} \mathrm{m}^{-3}$ (Table 1). The increase in the energy content was statistically significant $(p=0.00)$.
Fig. 3 Moisture content of the pine bark in various parts of the stockpile at the end of the experiment
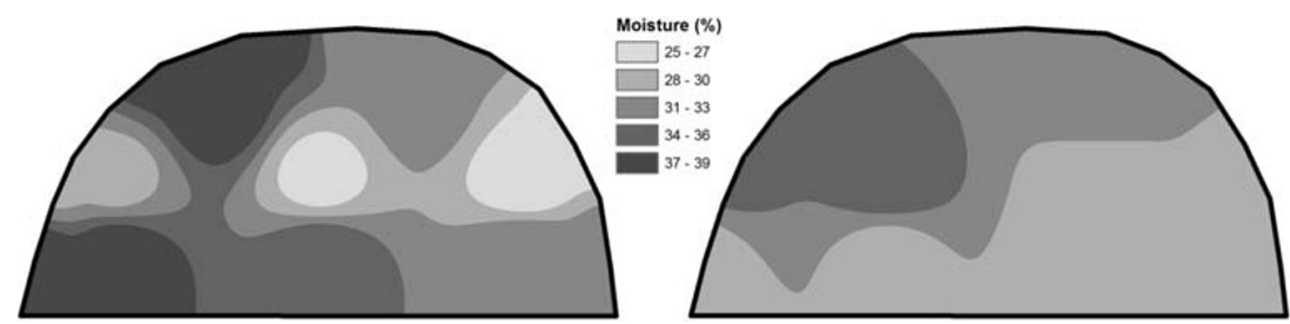


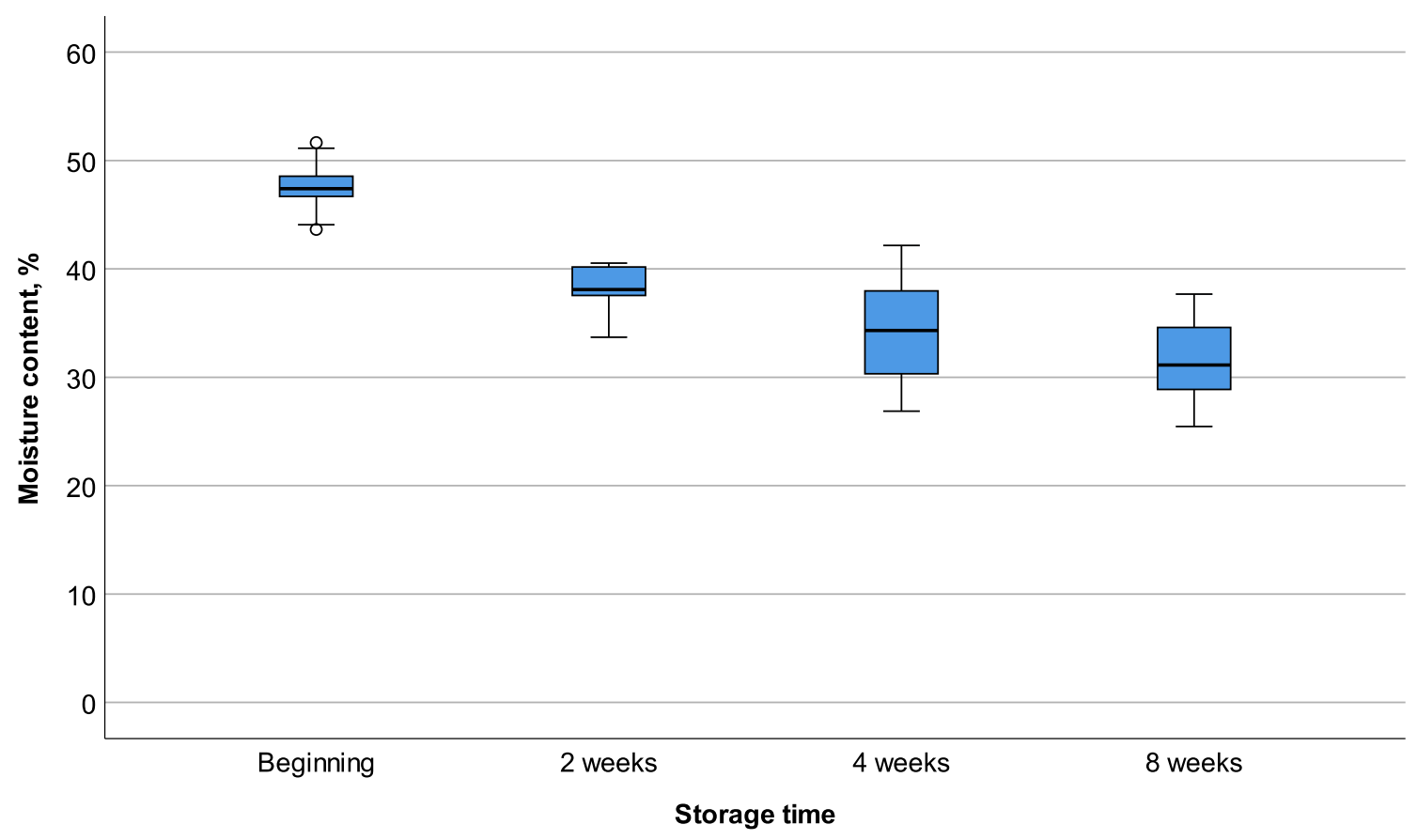

Fig. 2 Average moisture content of bark during 2, 4, and 8 weeks of storage

\section{Extractives}

The average extractives content of the fresh pine bark was 9.92\% $( \pm 0.43)$. At the beginning of the storage period, the extractives content decreased rapidly (Fig. 5 and Table 1). The duration of storage significantly affected the extractives content of pine bark $(p=0.000)$. ANOVA for the samples was executed only after storage $(2,4$, and 8 weeks). This was due to the small number of samples $(n=3)$ analyzed from fresh bark. A Bonferronicorrected $t$ test indicated no significant difference in the extract content of the samples between 2 and 4 weeks of storage $(p=$ 0.993). However, there was a significant difference in the extractives content of the samples between 4 and 8 weeks of storage $(p=0.000)$. The largest decrease in extractives content occurred during the first 2 weeks, when approximately $30 \%$ of the initial extractives content was lost.

The extractives content at the end of the experiment showed no statistically significant differences $(p=0.421-1.000)$ at the different levels of the pile (bottom, middle, and top). ANOVA could not be conducted to compare the extractives content in the middle of the pile with that at the sides of the pile due to the small and uneven number of observations between groups. Instead, the mean values of the extractives content were compared, and the following observations were made: After 4 weeks of storage, the average extractives content ( $\%$ of d.m.) was $7.61 \%$ in the middle of the pile and $7.11 \%( \pm 0.54)$ at the sides of the pile. After 8 weeks of storage, the extractives content was $5.92 \%$ and $5.63 \%$ $( \pm 0.27)$ in the middle and at the sides of the pile, respectively.

Table 1 The mean moisture content, basic density, calorific value, energy content, ash content, and extractives content of the pine bark before (initial) and after storage for 2-8 weeks (post-storage)

\begin{tabular}{|c|c|c|c|c|c|c|c|}
\hline $\begin{array}{l}\text { Time in } \\
\text { storage }\end{array}$ & $\begin{array}{l}\text { Moisture content, } \\
\text { average, } \%\end{array}$ & $\begin{array}{l}\text { Basic density, } \\
\text { average, } \mathrm{kg} \mathrm{m}^{3}\end{array}$ & $\begin{array}{l}\text { Net calorific value, } \\
\text { average, } \mathrm{MJ} \mathrm{kg}^{-1}\end{array}$ & $\begin{array}{l}\text { Net calorific } \\
\text { value as } \\
\text { received, } \\
\text { average, MJ } \\
\mathrm{kg}^{-1}\end{array}$ & $\begin{array}{l}\text { Energy } \\
\text { content, } \\
\text { MWh m }\end{array}$ & $\begin{array}{l}\text { Ash content, } \\
\text { average, } \%\end{array}$ & $\begin{array}{l}\text { Extractives } \\
\text { content, } \\
\text { average, \% }\end{array}$ \\
\hline Fresh bark & $47.48 \pm 2.04$ & $316 \pm 6.15$ & $19.70 \pm 0.13$ & $9.19 \pm 0.46$ & $1.54 \pm 0.03$ & $1.90 \pm 0.06$ & $9.92 \pm 0.43$ \\
\hline $\begin{array}{l}2 \text { weeks in } \\
\text { storage }\end{array}$ & $38.24 \pm 2.22$ & $310 \pm 7.80$ & $19.46 \pm 0.07$ & $11.08 \pm 0.48$ & $1.54 \pm 0.03$ & $1.97 \pm 0.05$ & $6.87 \pm 0.37$ \\
\hline $\begin{array}{l}4 \text { weeks in } \\
\text { storage }\end{array}$ & $34.28 \pm 5.35$ & $308 \pm 8.01$ & $19.48 \pm 0.21$ & $11.97 \pm 1.16$ & $1.56 \pm 0.04$ & $2.16 \pm 0.12$ & $7.12 \pm 0.70$ \\
\hline $\begin{array}{l}8 \text { weeks in } \\
\text { storage }\end{array}$ & $31.45 \pm 3.92$ & $309 \pm 5.81$ & $19.71 \pm 0.11$ & $12.74 \pm 0.88$ & $1.59 \pm 0.03$ & $1.97 \pm 0.05$ & $5.55 \pm 0.43$ \\
\hline
\end{tabular}

Results are presented with standard deviations 


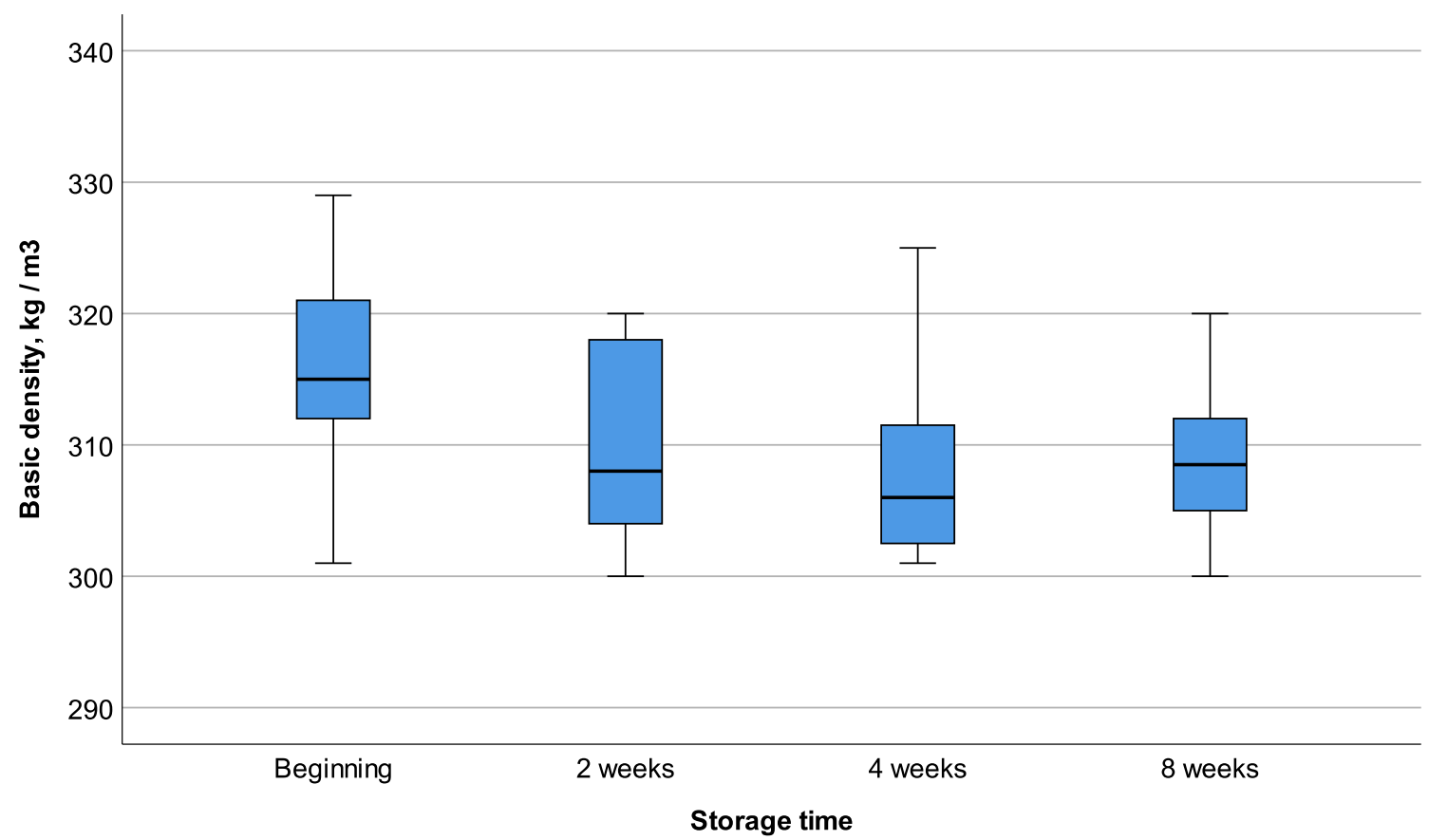

Fig. 4 Basic density change during 2, 4, and 8 weeks of storage

The standard deviation was relatively large, and the values were quite close to each other, so no differences in extractives content regarding its location in the pile were observed.

The qualitative GC/MSD analysis results for acetone extractives are presented in Table 2. The results of quantification are presented in Table 3 and Fig. 6 for different extractive groups.
The content of triglycerides (TG) decreased rapidly at the beginning of the storage period, and was approximately halved during the first 2 weeks of storage (Table 3 and Fig. 6). There was no significant difference in TG content between 2 and 4 weeks of storage $(p=0.058)$, but a significant difference was found between 4 and 8 weeks $(p=0.005)$. Most of the phenolic compounds quantified with GC/MSD (Table 2) were lost during

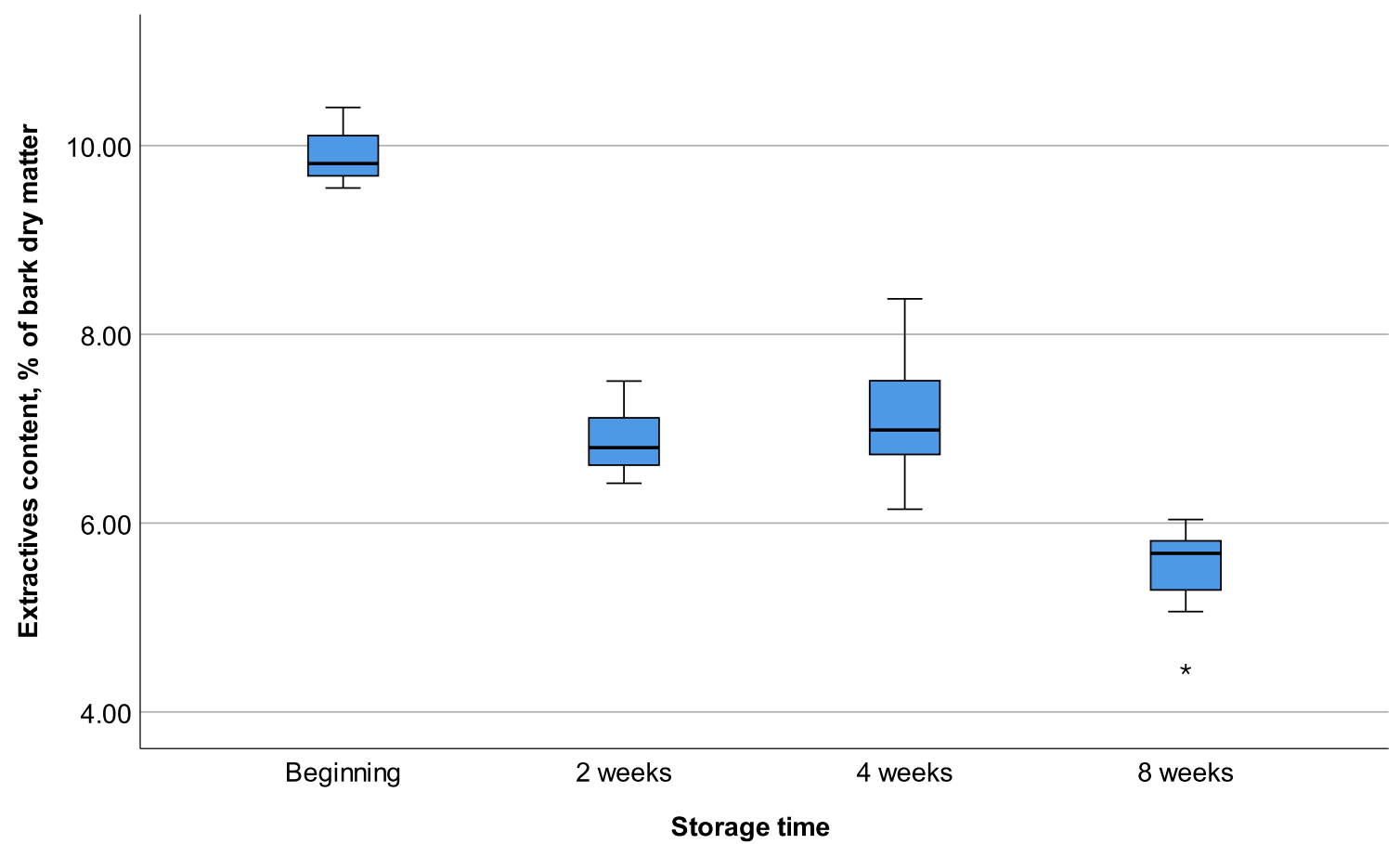

Fig. 5 Changes in gravimetric extractives content during 2, 4, and 8 weeks of storage compared to fresh spruce bark. There was one outlier, a sample taken from the top layer (marked with *) of the pile. 
the first 2 weeks of storage, with only a small amount of lignans, dihydroconiferyl alcohol, and taxifolin remaining after the 2week storage period. No other phenolic extractive compounds could be reliably detected and quantified after this period. The loss of dihydroconiferin was especially noteworthy. Fresh bark

Table 2 Qualitative gas chromatographic analysis results for extractives. Identified compounds are listed in order based on their retention times

\begin{tabular}{|c|c|c|}
\hline Peak no. & Retention time, min & Compound \\
\hline 1 & 5.1099 & Pinitol \\
\hline 2 & 5.194 & Dihydroconiferyl alcohol $^{\mathrm{b}}$ \\
\hline 3 & 7.776 & Palmitic acid $(16: 0)$ \\
\hline 4 & 8.728 & Margaric acid (17:0) \\
\hline 5 & 9.015 & Thunbergol \\
\hline 6 & 9.603 & Linolenic acid (18:3) \\
\hline 7 & 10.094 & Linoleic acid (18:2) \\
\hline 8 & 10.158 & Oleic acid (18:1) \\
\hline 9 & 10.524 & Stearic acid $(18: 0)$ \\
\hline 10 & 11.597 & Monomethyl pinosylvin ${ }^{a}$ \\
\hline 11 & 11.735 & Pimaric acid \\
\hline 12 & 11.9683 & Sandaracopimaric acid \\
\hline 13 & 12.1459 & Pinosylvin $^{\mathrm{a}}$ \\
\hline 14 & 12.225 & Isopimaric acid \\
\hline 15 & 12.42 & Palustric acid \\
\hline 16 & 12.542 & Unidentified resin acid \\
\hline 17 & 12.613 & Eicosatrienoic acid (20:3) \\
\hline 18 & 12.725 & Levopimaric acid \\
\hline 19 & 12.912 & Dehydroabietic acid \\
\hline 20 & 13.391 & Abietic acid \\
\hline 21 & 14.281 & Hydroxydehydroabietic acid \\
\hline 22 & 14.345 & Abietatetraenoic acid \\
\hline 23 & 14.654 & Neoabietic acid \\
\hline 24 & 14.786 & ISTD Heneicosanoic acid (21:0) \\
\hline 25 & 14.8685 & Docosanol \\
\hline 26 & 14.957 & Hydroxydehydroabietic acid \\
\hline 27 & 15.209 & Isodehydroabietic acid \\
\hline 28 & 15.437 & Unidentified hydroxy resin acid \\
\hline 29 & 15.564 & Hydroxydehydroabietic acid \\
\hline 30 & 15.953 & 7-Oxo-dehydroabietic acid \\
\hline 31 & 16.169 & Behenic acid $(22: 0)$ \\
\hline 32 & 16.381 & Unidentified hydroxy resin acid \\
\hline 33 & 17.269 & Dihydroxydehydroabietic acid \\
\hline 34 & 17.541 & Tricosanoic acid $(23: 0)$ \\
\hline 35 & 17.5876 & Tetracosanol \\
\hline 36 & 17.701 & 1-Mono-oleoylglycerol \\
\hline 37 & 18.324 & Hydroxy-7-oxodehydroabietic acid \\
\hline 38 & 18.844 & Lignoceric acid (24:0) \\
\hline 39 & 19.407 & Catechin $^{\mathrm{a}}$ \\
\hline 40 & 19.788 & Dihydroconiferin $^{\mathrm{a}}$ \\
\hline 41 & 20.514 & Taxifolin ${ }^{\mathrm{b}}$ \\
\hline 42 & 20.581 & 22-Hydroxydocosanoic acid \\
\hline 43 & 20.925 & Secoisolariciresinol \\
\hline 44 & 21.377 & Cerotic acid (26:0) \\
\hline 45 & 22.935 & Behenoyl-glycerol \\
\hline 46 & 23.287 & Matairesinol \\
\hline 47 & 24.199 & Campesterol \\
\hline 48 & 25.206 & Sitosterol \\
\hline 49 & 26.846 & Stigmast-4-en-3-one \\
\hline 50 & 27.581 & ISTD Betulin \\
\hline 51 & 28.509 & Taxifolin glycoside ${ }^{\mathrm{a}}$ \\
\hline
\end{tabular}

${ }^{\text {a }}$ Phenolic extractives lost during the two 2 weeks of storage

${ }^{\mathrm{b}}$ Phenolic extractives lost between 4 and 8 weeks of storage contained $2.25 \pm 0.09 \mathrm{mg} / \mathrm{g}$ dihydroconiferin, which was not detected after 2 weeks of storage. The differences between the content after 2, 4, and 8 weeks were significant $(p=0.000)$, whereas no significant differences in the content of sterols $(p=$ 1.000) were observed between 2 and 4 weeks of storage, although differences in content were observed between 4 and 8 weeks $(p=0.000)$. In the case of steryl esters, there was no significant difference in content between 2,4 , or 8 weeks of storage $(p=1.000)$. The content of free fatty acids roughly doubled during the first 2 weeks of storage. The Games-Howell post hoc test indicated that there was a significant difference in the fatty acid content between 2 and 8 weeks of storage $(p=0.045)$. The content of resin acids decreased during the first 2 weeks of storage, and then remained relatively stable, with no significant differences observed between the 2-, 4-, and 8-week storage periods $(p=0.074-0.745)$.

At the beginning of the study, the CT content in the bark was $3.51 \mathrm{~g} / 100 \mathrm{~g}( \pm 0.04)$ (Fig. 7). Thiolytic degradation released subunits (flavan-3-ols) with structures of catechin and epicatechin, indicating that $\mathrm{CT}$ in pine bark essentially consisted of procyanidins. CT content was $1.28 \mathrm{~g} / 100 \mathrm{~g}( \pm 0.01), 1.18 \mathrm{~g} / 100$ $\mathrm{g}( \pm 0.01)$, and $0.91 \mathrm{~g} / 100 \mathrm{~g}( \pm 0.15)$ after storage for 2,4 , and 8 weeks, and the differences in content were significant $(p=$ $0.001-0.012$ ). Thus, after 2 weeks of storage, more than $60 \%$ of the initial content was lost, after which CT content remained relatively steady, although it still declined slightly. The average degree of polymerization in $\mathrm{CT}$ was highest at the beginning of the study and then declined, especially during the first 2 weeks. Generally, no significant differences could be observed in samples taken from different levels of the pile, except after 8 weeks of storage, when CT content at the top $(0.735 \pm 0.108 \mathrm{~g} / 100 \mathrm{~g})$ of the pile was significantly lower than in the middle $(0.976 \pm 0.252$ $\mathrm{g} / 100 \mathrm{~g})$ or at the bottom $(1.020 \pm 0.345 \mathrm{~g} / 100 \mathrm{~g})$.

\section{Discussion}

The aim of this study was to determine the changes in quality characteristics and extractive content during the storage of pine bark in order to evaluate the effect of storage on bark for bioenergy use and the suitability of bark for biorefining.

The temperature development in the pine bark pile was rapid, reaching $60{ }^{\circ} \mathrm{C}$ within 3 days, but declining after 3 weeks to around $30^{\circ} \mathrm{C}$. In coniferous bark piles, the temperature reached $60-65^{\circ} \mathrm{C}$ within a few days, and then stabilized at $60{ }^{\circ} \mathrm{C}$ for several weeks, similar to the results in studies by Lehtikangas and Jirjis [45], Krigstin et al. [46], and Routa et al. [29]. A complicating factor is that the sampling of bark during storage causes a disturbance in the piles and can lead to biased results. The moisture content of the pine bark pile at the beginning of the experiment was quite low, and significant drying occurred (by 16\%) during the 2-month storage period. The net bag analyses showed that the driest areas at the end of 
Table 3 Changes in the content (mg/g dry bark) of different extractive compound groups during storage

\begin{tabular}{|c|c|c|c|c|c|c|c|}
\hline Time in storage & Fatty acids & Resin acids & Sterols & Phenolic extractives & Other lipophil. & Steryl esters & Triglycerides \\
\hline Fresh bark & $1.81 \pm 0.12$ & $9.93 \pm 0.59$ & $1.23 \pm 0.04$ & $3.88 \pm 0.15$ & $0.40 \pm 0.01$ & $2.50 \pm 0.05$ & $12.37 \pm 0.34$ \\
\hline 2 weeks & $3.58 \pm 0.07$ & $7.47 \pm 0.27$ & $1.27 \pm 0.09$ & $0.30 \pm 0.03$ & $0.34 \pm 0.01$ & $2.22 \pm 0.21$ & $6.13 \pm 0.66$ \\
\hline 4 weeks & $3.58 \pm 0.21$ & $7.59 \pm 0.33$ & $1.24 \pm 0.12$ & $0.13 \pm 0.02$ & $0.35 \pm 0.02$ & $2.21 \pm 0.18$ & $5.12 \pm 0.40$ \\
\hline 8 weeks & $3.22 \pm 0.49$ & $7.05 \pm 0.73$ & $1.02 \pm 0.10$ & $0.04 \pm 0.01$ & $0.35 \pm 0.04$ & $2.19 \pm 0.38$ & $3.85 \pm 1.02$ \\
\hline
\end{tabular}

Standard deviations for the results are given in the table. Compound groups fatty acids, resin acids, sterols, phenolic extractives, and other lipophilic compounds were quantified with a long capillary column (ZB-SemiVolatiles), and steryl esters and triglycerides with a short capillary column (DB1HT). The phenolic compound group in this table includes compounds with peak numbers 2, 10, 13, 39-41, 43, 46, and 51 (Table 2).

the experiment were in the middle of the pile, but the values only refer to their specific position in the pile.

The average net calorific value $\left(\mathrm{q}_{\mathrm{p}, \text { net, } \mathrm{d}}\right)$ of the bark did not change during the experiment, as also reported by Lehtikangas and Jirjis [45]. However, the net calorific value as received (qp,net,ar) increased markedly, since the bark moisture content decreased during storage. The energy content $\left(\mathrm{MWh} \mathrm{m}^{-3}\right)$ of the pile increased during the 8 -week storage, and at the same time the moisture content decreased by $16 \%$. The ash content of the pine bark was $1.89 \%$ at the beginning of the experiment and $1.97 \%$ at the end, similar to the levels reported by Lehtikangas and Jirjis [45] and Saarela et al. [47]. During the 8-week storage, the basic density of the pine bark decreased by $2.3 \%$.

According to Koskinen [6] and Agin and Svensson [7], wood loss of 1-6\% is normal with drum-debarked pulp wood. In this study, rotary debarking was used for sawlogs, and a relatively high amount of wood (19.6\%) was observed in saw bark streams. In this experimental pile, such a high percentage of wood may have affected the heat development in the pile compared with other study results.

In favorable weather conditions, the bark pile can dry markedly during storage. The bark was stored from August to October, which is a relatively short storage period for an industry in which production runs during all seasons. However, sawmills are usually shut down in July for maintenance. After the shutdown, the bark starts to accumulate, and the need for energy is low, whereas large amounts of bark need to be stored. Thus, the most problematic time is in the autumn season, and therefore the storage test was timed specifically for that time period.

During the storage period, the ambient temperature and total precipitation were slightly higher than the long-term average (1981-2010) obtained from the Finnish Meteorological
Fig. 6 Changes in the content of different extractive groups during storage. Results are based on GC/ MS analysis of acetone extracts. Standard deviation for the quantification of all the compounds is shown in the figure

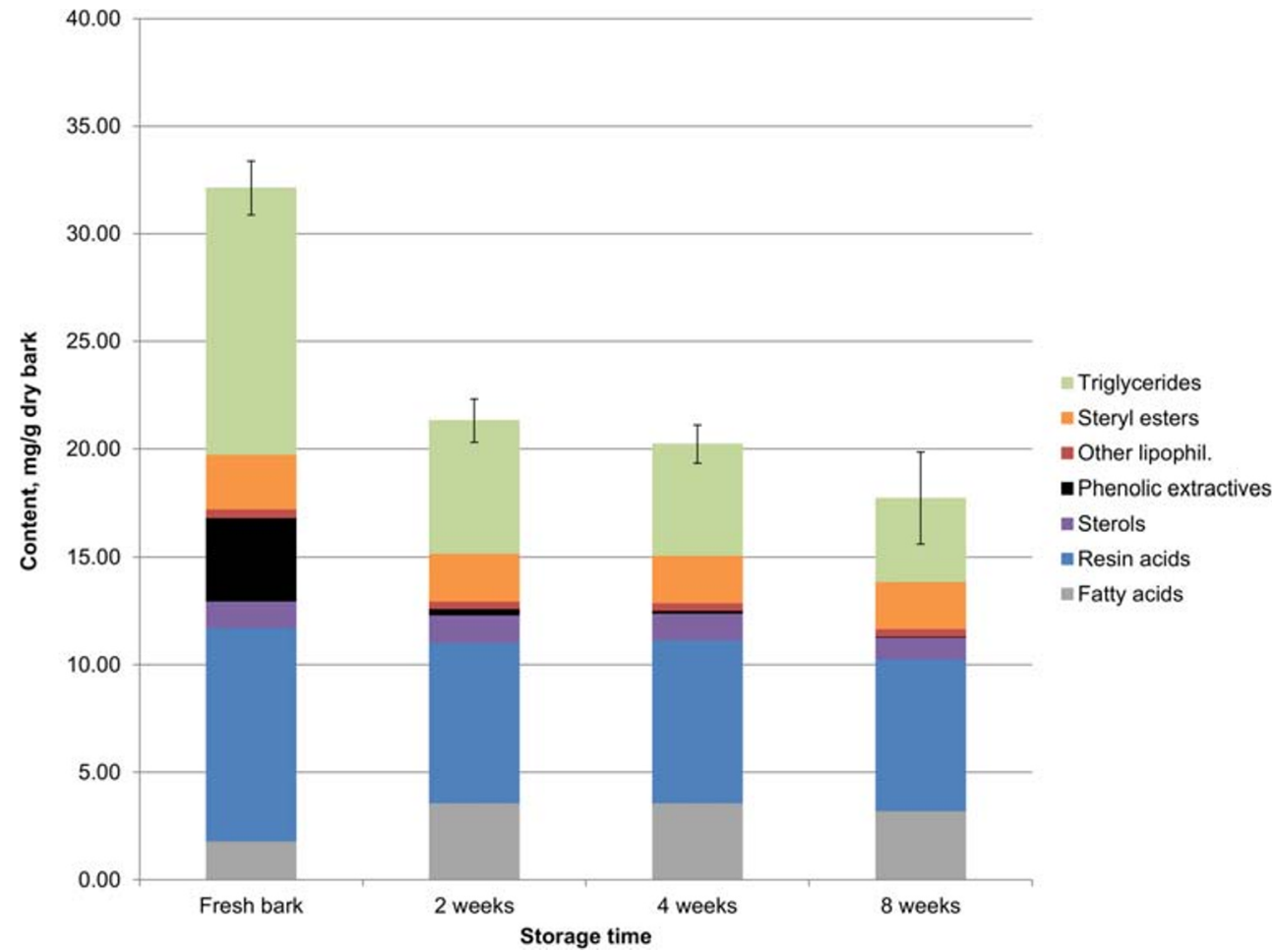




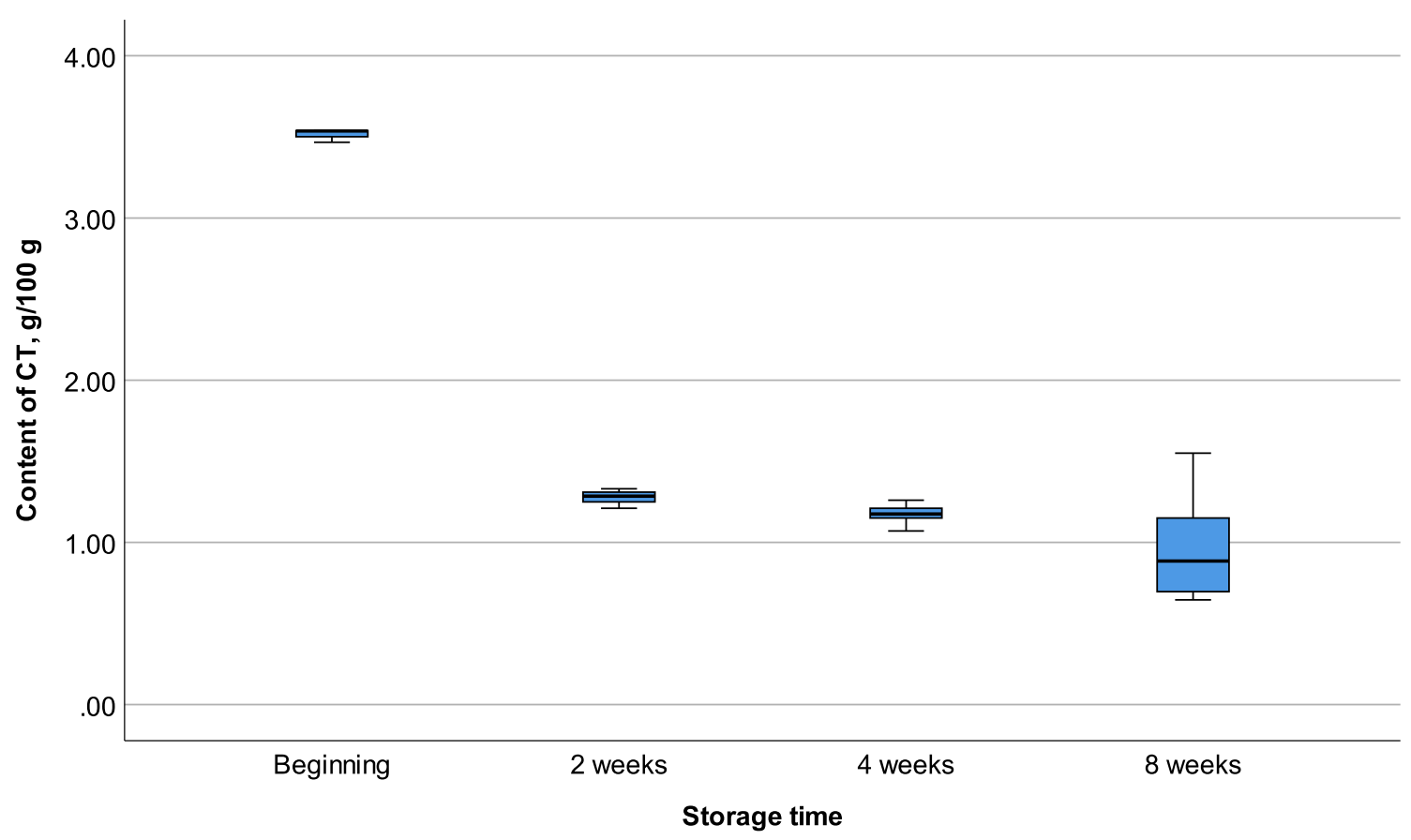

Fig. 7 Decreases in content of condensed tannins during 2, 4, and 8 weeks of storage compared to fresh spruce bark

Institute [48]. The experiment ended in the middle of October, and so the pile was not exposed to heavy rain or snow. If the pile had been stored over the winter, it would have had to have been covered. Covering the biomass to protect it from rain and snow can both increase the drying performance and reduce the risk of dry matter loss $[28,49]$. However, the cover material applied must allow ventilation of water vapor and heat.

The most significant changes in extractives content and composition occurred within the first 2 weeks of storage. A similar rate of decrease was reported in Norway spruce bark extractives content during the first 2 weeks of storage, although the extractives content of spruce bark was higher $(11.83 \pm 0.13 \%$ d.m. $)$ at the beginning [29]. However, a greater share of the extractives were lost from Scots pine bark during the 8-week storage. The content of pine bark extractives decreased from $9.92 \pm 0.43$ to $5.55 \pm 0.43$ (\% d.m.) during the 8 weeks, whereas the spruce bark extractives content after 8 weeks of storage was still $7.83 \pm 0.29$ (\% d.m.). It should be noted that these storage studies were conducted simultaneously, and the environmental conditions were therefore the same. The experimental setups were also similar, there were no significant differences in pile size, and storage locations were in close proximity to one another. Thus, the observed differences in the extractives losses may be a result of the differences in the properties of the bark materials, i.e. in their extractive composition or chemical composition in general, and the structural properties of the bark. The structure and chemical composition of woody material significantly influence its degradation by microorganisms [50]. In the case of softwood bark (mixture of Norway spruce and Scots pine pulp mill barks), the most significant changes in extractives content were likewise observed at the beginning of the storage period, i.e. after the first week of storage [51]. The amount of extractives in the bark material was almost halved during the first 4 weeks of storage $[14,51]$.

Neither the Norway spruce bark [29] nor the Scots pine bark storage in this experiment showed statistically significant differences in extractives content at the different levels of the pile (bottom, middle, and top). This result differs from the results for Norway spruce bark storage by Halmemies et al. [52], who observed that the different sampling locations in the pile had a clear effect on extractives content. They found that the rate of decrease in extractives content was fastest at the top of the pile, slowest in the middle, and somewhere in between at the sides of the pile. These differences between the studies may be due to the different tree species, pile dimensions, sampling locations, and storage seasons. The differences may also be partly explained by the differences in extraction methods and the solvents used. There may also have been differences in the properties of the stored bark (e.g. age and origin of harvested stems, particle size of bark, and density of the bark pile).

The composition of the extractives fraction changed during the 8-week storage period. The content of triglycerides decreased rapidly at the beginning of the storage period, and was approximately halved during the first 2 weeks of storage. As a result of the hydrolysis of triglycerides and possibly other compounds (e.g. steryl esters), the amount of free fatty acids increased at the beginning of the storage period. The increase in the amount of 18:1, 18:2, and 22:0 fatty acids was most remarkable. Most of the phenolic compounds quantified with GC/ MS were lost during the first 2 weeks of storage. Only a small amount of lignans, dihydroconiferyl alcohol, and taxifolin remained after the 2-week storage period. After 8 weeks of 
storage, the lignans were the only phenolic compounds that could be detected from acetone extract with GC/MS. The content of resin acids decreased during the first 2 weeks of storage, after which it remained relatively stable. The content of levopimaric, isopimaric, and neoabietic acids decreased most significantly. A decrease in the concentration of abietic acid was also noted. Lappi et al. [51] also observed a decrease in TG content and the content of interesting phenolic compound groups such as lignans during softwood pulp mill bark storage.

CTs in Scots pine bark essentially comprised procyanidins, in line with previous studies [53, 54]. However, both Bianchi et al. [53] and Matthews et al. [54] determined somewhat higher CT content in pine bark than that in the present study. Naturally, some variation is expected, but the relatively low CT content in the present study may be explained in part by the relatively high proportion of non-bark material, i.e. wood, included in the samples. Wood is not expected to contain CT.

$\mathrm{CT}$ content in the pine bark decreased during storage, especially in the first 2 weeks. Similar results were found in a study by Mupondi et al. [55], in which storage of pine bark for 90 days led to significant CT loss. While CT is known to be a relatively resistant substance and not easily decomposed in nature, it is also known that CT-rich material such as tree bark is often occupied by CT-utilizing bacteria and fungi [56-58]. Rapid self-heating of the bark piles indicates high microbial activity, and it is very likely that $\mathrm{CT}$ loss in bark during storage is largely accounted for by microbial activity. The microbial degradation of CT has long been documented [59]. The generation of heat may also accelerate the oxidation of $\mathrm{CT}$, resulting in further loss. Over time, CT can also form complexes with proteins and other macromolecules, and become more resistant for thiolysis [56, 60], and therefore partially escape detection with the method used in the present study.

The utilization of bark extractives as raw materials for highvalue applications requires raw material freshness. Due to the rapid changes occurring in bark extractive fractions during pile storage, it can be concluded that bark should be sent for further processing as soon as possible after debarking. Otherwise, sufficient yields in further processing phases will be compromised as a result of decreased extractives content and changes in the chemical composition of the extractive fractions. In this study the yield of acetone extract decreased about $30 \%$ after 2 weeks of storage. The CT content decreased even more, as over $60 \%$ of CTs were lost during the same time. This is bound to have an effect on feasible production of CTs and CT-based products, as not only does the amount change, but some less soluble CT-based compounds may also be formed.

The time between harvesting and debarking, the transportation method (by truck or log floating), and the harvesting method (cut-to-length or tree length) affect the characteristics of the bark. The whole supply chain must be efficient to ensure fast delivery; the loss of bark has to be avoided during harvest and transport, and the bark must be kept clean from impurities such as mineral soil. This is not a problem for harvesting companies using the cut-to-length method and modern enterprise resource planning systems for harvest and transportation, and it also supports the supply of industrial wood, in which the goal is to deliver the trees to the factory in as fresh a state as possible.

The storage behavior of bark extractives is not a wellstudied topic. Previous studies of bark storage have been conducted mainly in the context of bioenergy production, and thus the changes in chemical composition have not been investigated extensively. In order to fill the gaps in current knowledge and to better serve the emerging biorefining industry, it would be beneficial to conduct more industrial-scale storage studies for softwood bark and to perform detailed chemical characterization of storage samples.

Systematic studies of the effect of season on the pile storage of bark are also needed, as well as comparative investigations of the effects of different storage methods on bark chemistry. Industrial biorefineries utilizing extractive compounds of wood biomass have more steady year-round demand for feedstock than, for example, the bioenergy sector, which is more dependent on the changing seasons. For this reason, the effect of season on changes in the chemical composition of bark is an important topic that warrants further research.

\section{Conclusions}

Biomass storage can have a substantial influence on bioenergy or biofuel economic feasibility, and on the potential environmental benefits. From the energy perspective, this study clearly showed that the energy content $\left(\mathrm{MWh} \mathrm{m}^{-3}\right)$ of the bark pile can increase during storage, while at the same time the moisture content decreases. On the other hand, in poor storage conditions, the energy content and the quality of fuel can decrease markedly.

The results of this study confirm that extractive losses occur rapidly after debarking of wood and piling of the bark, which means that to utilize these valuable compounds, the supply chain from the forest should be accelerated, and material should be sent for further processing as soon as possible after debarking. The results clearly demonstrate that hydrophilic, phenolic extractive compounds in particular are rapidly lost after debarking and piling of bark. About $60 \%$ of CTs were lost after 2 weeks of storage, after which the $\mathrm{CT}$ content remained rather steady, albeit still declining slightly. About $26 \%$ of the quantified lipophilic compounds were lost after 2 weeks of storage, and $63 \%$ of the lipophilic compounds still remained at the end of the storage period. The magnitude of the changes in extractives fraction was thus highest in the beginning of the storage period, when most of the changes and losses occurred in both lipophilic and hydrophilic extractives.

Improving bark storage conditions could increase the energy content and decrease the moisture content of the bark, thus improving the raw material for energy use. However, storage 
of bark significantly decreases the quality of the raw material for biorefineries. Therefore, the comprehensive utilization of bark requires that efficiency be maintained throughout the supply chain to ensure that tree delivery times are kept short and that loss of bark is avoided during harvest and transport.

Acknowledgements We gratefully acknowledge the technical assistance of Perttu Anttila, Jaakko Miettinen, Matti Savinainen, Mikko Karjalainen, Tapio Laakso, Pauli Karppinen, Satu Örling, and Reetta Kolppanen of Luke. Risto Korpinen from Luke is thanked for assistance in chemical analysis and valuable discussions related to the topic. We thank Stora Enso Uimaharju Sawmill, and especially Jorma Kaukoaho and Harri Valkonen, for organizing the storage experiment.

Author contributions Johanna Routa (JR) and Hanna Brännström (HB) were the main writers of the original draft. Jarkko Hellström $(\mathrm{JH})$ and Juha Laitila (JL) reviewed and edited the manuscript. JR and HB designed the experiments, and JR, HB, and JL carried out the experiments. $\mathrm{JR}, \mathrm{HB}$, and JH analyzed the data, and JH contributed to sample preparation. All authors provided critical feedback and helped shape the research, analysis, and manuscript.

Funding Open access funding provided by Natural Resources Institute Finland (LUKE). The authors gratefully acknowledge financial support from the Natural Resources Institute Finland Harvesting alternatives for land clearing wood and buffer storing of comminuted wood biomass$H a B u$ project, European Regional Development Fund Local Divided Bioenergy as Solution project [grant number: A71770], and the Strategic Research Council of the Academy of Finland, FORBIO Sustainable, climate-neutral and resource-efficient forest-based bioeconomy project [grant number 314224].

Open Access This article is licensed under a Creative Commons Attribution 4.0 International License, which permits use, sharing, adaptation, distribution and reproduction in any medium or format, as long as you give appropriate credit to the original author(s) and the source, provide a link to the Creative Commons licence, and indicate if changes were made. The images or other third party material in this article are included in the article's Creative Commons licence, unless indicated otherwise in a credit line to the material. If material is not included in the article's Creative Commons licence and your intended use is not permitted by statutory regulation or exceeds the permitted use, you will need to obtain permission directly from the copyright holder. To view a copy of this licence, visit http://creativecommons.org/licenses/by/4.0/.

\section{References}

1. European Commission (2013) Green Paper: A 2030 Framework for Climate and Energy Policies. COM https://eur-lex.europa.eu/ LexUriServ/LexUriServ.do?uri=COM:2013:0169:FIN:en:PDF. Assessed 15 August 2020.

2. European Commission (2014) Communication from the Commission to the European Parliament, the Council, the European Economic and Social Committee and the Committee of the Regions: A policy framework for climate and energy in the period from 2020 to 2030. https://eur-lex.europa.eu/legal-content/ EN/TXT/PDF/?uri=CELEX:52014DC0015\&from=EN. Assessed 15 August 2020

3. Official statistics Finland (2016) Energy supply and consumption, Helsinki, Statistics Finland http://www.stat.fi/til/ehk/2016/ehk 2016_2017-12-08_tie_001_en.html. Accessed 15 August 2020
4. Official statistics Finland (2017) Wood in energy generation, Helsinki, Natural Resources Institute Finland: http://stat.luke.fi/ puun-energiakaytto. Accessed 15 August 2020

5. Isokangas A (2010) Analysis and management of wood room. Dissertation. Acta universitatis Ouluensis C technical 363. Faculty of Technology, Department of Process and Environmental Engineering University of Oulu.

6. Koskinen K (1999) Wood handling applications. In: Gullichsen J, Fogelholm CJ (eds) Papermaking Science and Technology, Book 6A. Chemical pulping. Fapet Oy. Helsinki, pp 331-491

7. Agin SA, Svensson $\AA$ (1990) Fibre losses - economic consequences for the wood yard processes. Proc 24th Eucepa Conference, Stockholm, pp. 47-55.

8. Bajpai P (2015) Green Chemistry and Sustainability in Pulp and Paper Industry. Springer International Publishing Switzerland.

9. Routa J, Kolström M, Sikanen L (2018) Dry matter losses and their economic significance in forest energy procurement. IJFE 29:5362. https://doi.org/10.1080/14942119.2018.1421332

10. Krigstin S, Wetzel S (2016) A review of mechanisms responsible for changes to stored woody biomass fuels. Fuel 175:75-86. https:// doi.org/10.1016/j.fuel.2016.02.014

11. Nurmi J (1993) Heating values of the above ground biomass of small-sized trees. Acta Forestalia Fennica 236:1-30. http://hdl. handle.net/1975/9342

12. Nurmi J (1997) Heating values of mature trees. Acta Forestalia Fennica 256:1-28. http://hdl.handle.net/10138/27295

13. Voipio R, Laakso T (1992) Pienikokoisten puiden maanpäällisen biomassan kemiallinen koostumus (Chemical composition of the above ground biomass of small-sized trees). Folia Forestalia 789. [summary in English].

14. Routa J, Brännström $H$, Anttila $P$, Mäkinen $M$, Jänis J, Asikainen $A$ (2017) Wood extractives of Finnish pine, spruce and birch - availability and optimal sources of compounds: A literature review. Natural resources and bioeconomy studies 73. Natural Resources Institute Finland, Helsinki. 55 p. http://urn.fi/URN:ISBN:978-952-326-495-3

15. Arshadi M, Eriksson D, Isacsson,P, Bergsten U (2018) Bark Assortments of Scots Pine and Norway Spruce as Industrial Feedstock for Tall Oil Production. Forests 9(6): 332. https://doi. org/10.3390/f9060332

16. Miranda I, Gominho J, Mirra I, Pereira H (2012) Chemical characterization of barks from Picea abies and Pinus sylvestris after fractioning into different particle sizes. Industrial Crops and Products 36(1):395400. https://doi.org/10.1016/j.indcrop.2011.10.035

17. Steinshamn H (ed) (2014) Bark in feed - for improved feed utilization and animal health. Bioforsk Fokus 9(10):1-54 http://hdl. handle.net/11250/2444067

18. Bianchi S (2017) Extraction and characterization of bark tannins from domestic softwood species. Doctoral thesis, University of Hamburg, Germany.

19. Kemppainen K (2015) Production of sugars, ethanol and tannin from spruce bark and recovered fibres. VTT Science 76, Doctoral thesis, Aalto University, Espoo, Finland.

20. Pizzi A (2008) Tannins: Major sources, properties and applications. In: Belgacem MN, Gandini A (eds) Monomers, Polymers and Composites from Renewable Resources. Elsevier, Oxford, UK, pp 179-199

21. Anonymous. Silvateam. https://www.silvateam.com/en/. Accessed 15 March 2019.

22. Peltonen S (1981) Studies on bark extracts from Scots pine (Pinus sylvestris) and Norway spruce (Picea abies). Paperi ja puu 63:681-687

23. Höfer R (2015) The pine biorefinery platform chemicals value chain. In: Pandey A, Höfer R, Taherzadeh M, Nampoothiri KM, Larroche (eds.), Industrial biorefineries \& white biotechnology. Elsevier, Amsterdam, pp. 127-155.

24. Phun L, Snead D, Hurd P, Jing F (2017) Industrial applications of pine-chemical-based materials. In: Tang C, Ryu CY (eds.), 
Sustainable polymers from biomass, Wiley-VCH Verlag GmbH \& Co. KGaA, pp. 151-180.

25. Anonymous (2016) Global impact of the modern pine chemical industry. Retrieved from https://cdn.ymaws.com/www. pinechemicals.org/resource/resmgr/Studies/PCA-_Global_Impact of the Mo.pdf. Pine Chemical Association.

26. Fredholm R, Jirjis R (1988) Säsongslagring av bark från våtlagrade stocker. Sveriges lantbruksuniversitet, Institutionen för virkeslära. [summary in English].

27. Anheller M (2009) Biomass Losses during Short-term Storage of Bark and Recovered Wood. Examensarbete, Institutionen för energi och teknik, SLU, Uppsala.

28. Anerud E, Routa J, Bergström D, Eliasson L (2020) Fuel quality of stored spruce bark - Influence of semi-permeable covering material. Fuel 279:-118467. https://doi.org/10.1016/j.fuel.2020.118467

29. Routa J, Brännström H, Laitila J. The effects of storing spruce bark on its energy content and the amount of extractives. Accepted to Biomass Bioenergy.

30. Back EL (1981) Auto-ignition in hygroscopic, organic materials especially forest products - as initiated by moisture absorption from the ambient atmosphere. Fire Saf. J. 4:185-196. https://doi.org/10. 1016/0379-7112(81)90017-5

31. Assarsson A, Croon I, Donetzhuber A (1963) Studies on wood resin especially change in chemical composition during seasoning of wood. Svensk Papperstidning-Nordisk Cellulosa 22:940-948

32. Jirjis R, Theander O (1990) The effect of seasonal storage on the chemical composition of forest residue chips. Scand. J. For. Res 5: 437-448. https://doi.org/10.1080/02827589009382626

33. Ekman R (2000) Resin during storage and in biological treatment, In E-L. Back (ed.), Pitch Control, Wood Resin and Deresination. Tappi Press, Atlanta, pp 37-76

34. Lappi H, Nurmi J (2014) Decrease in extractives of chain-flail residue. Forest Refine info sheet 2014s. 3 p. Available: http:// biofuelregion.se/wp-content/uploads/2017/01/3_13_IS_2014-0812_Decrease_in_Extractives_of_CFResid_Lappī_Nurmi.pdf. Accessed on 13 Septem 2020.

35. Zahri S, Belloncle C, Charrier F, Pardon P, Quideau S, Charrier B (2007) UV light impact on ellagitannins and wood surface colour of European oak (Quercus petraea and Quercus robur). Appl Surf Sci. 253(11):4985-4989. https://doi.org/10.1016/j.apsusc.2006.11.005

36. Zhang L, Gellerstedt G (1994) Reactive structures in wood and high-yield pulps. IV. Daylight-induced oxidation of stilbene structures. Acta Chem Scand. 48:490-497

37. Eklund PC, Långvik OK, Wärnå JP, Salmi TO, Willför SM, Sjöholm RE (2005) Chemical studies on antioxidant mechanisms and free radical scavenging properties of lignans. Org Biomol Chem. 3(18):3336-3347. https://doi.org/10.1039/b506739a

38. SFS-EN 14774-2 (2010). "Solid biofuels. Determination of moisture content. Oven dry method. Part 2: Total moisture. Simplified method," Finnish Standards Association, Helsinki, Finland.

39. SFS-EN 14775 (2010). "Solid biofuels. Determination of ash content," Finnish Standards Association, Helsinki, Finland.

40. SCAN-CM 43:95 (1995). "Wood chips for pulp production. Basic density", Scandinavian Pulp, Paper and Board Testing Committee, Stockholm, Sweden.

41. CEN/TS 14918 (2005) "Solid Biofuels". "Method for the determination of calorific value", Finnish Standards Association. Helsinki, Finland

42. Alakangas E, Impola, R (2015) Quality guidelines for wood fuels in Finland. The Bioenergy Association of Finland, Finnish Energy, Finnish Forest Industries Federation, report VTT-M-04712-15: 1-59.

43. Örså F, Holmbom BA (1994) Convenient Method for the Determination of Wood Extractives in Papermaking Process Waters and Effluents. J. Pulp Paper Sci. 20:J361-J366

44. Mattila P, Pihlava JM, Hellström J, Nurmi M, Eurola M, Mäkinen S, Jalava T, Pihlanto A (2018) Contents of phytochemicals and antinutritional factors in commercial protein- rich plant products. Food Qual Saf. 2:213-219. https://doi. org/10.1093/fqsafe/fyy021

45. Lehtikangas P, Jirjis R (1998) Lagring av torrflis och bark I norra Sverige (Storage of wood chips and bark in Northern Sweden), Department of forest products, Report 254, p.30. [summary in English]

46. Krigstin S, Helmeste C, Jia H, Johnson KE, Wetzel S, Volpe S, Faizal W, Ferrero F (2019) Comparative analysis of bark and woodchip biomass piles for enhancing predictability of self-heating. Fuel 242:699 709. https://doi.org/10.1016/j.fuel.2019.01.056

47. Saarela KE, Harju L, Lill SJ, Heselius SJ, Rajander J, Lindroos A (2005) Quantitative Elemental Analysis of Dry-Ashed Bark and Wood Samples of Birch, Spruce and Pine from South-Western Finland Using PIXE. Acta Academiae Aboensis 2005, SER. B Vol. $64 \mathrm{nr} 1.36 \mathrm{p}$.

48. Pirinen P, Simola H, Aalto J, Kaukoranta JP, Karlsson P, Ruuhela R (2012) Climatological statistics of Finland 1981-2010, Finnish Meteorological Institute, Reports 2012.

49. Jiris R, Lehtikangas P (1993) Fuel quality and dry matter loss during storage of logging residues in a stack. Swedish University of Agricultural Sciences. Department of Forest Products, Report 236.

50. Eriksson KE, Blanchette R, Ander P (1990) Microbial and Enzymatic Degradation of Wood and Wood Components. Springer-Verlag, Berlin, Germany, p 407

51. Lappi H, Nurmi J, Läspä O (2014) Decrease in extractives of tree bark during storage. Forest Refine info sheet 2014. Available: http://biofuelregion.se/wp-content/uploads/3 11 IS 2014-08-11 Decrease_in_Extractives_Lappi_Nurmi_Laspa.pdf. Accessed on September 13, 2020.

52. Halmemies, E.; Brännström, H.; Nurmi, J.; Alén, R. The degradation of bark extractives-derived phenolics during storage. In NWBC 2018, Proceedings of the 8th Nordic Wood Biorefinery Conference, Helsinki, Finland, October 23-25, 2018; Hytönen, E., Vepsäläinen, J., Eds. VTT Technical Research Centre of Finland Ltd: Espoo, Finland, 2018.

53. Bianchi S, Kroslakova I, Janzon R, Mayer I, Saake B, Pichelin F (2015) Characterization of condensed tannins and carbohydrates in hot water bark extracts of European softwood species. Phytochem. 120:53-61. https://doi.org/10.1016/j.phytochem.2015.10.006

54. Matthews S, Mila I, Scalbert A, Connelly DMX (1997) Extractable and non-extractable proanthocyanidins in barks. Phytochem. 45: 405-410. https://doi.org/10.1016/S0031-9422(96)00873-4

55. Mupondi LT, Mnkeni PNS, Brutsch MO (2006) The effects of goat manure, sewage sludge and effective microorganisms composting of pine bark. Compost Sci Util 14:201-210. https://doi.org/10. 1080/1065657X.2006.10702284

56. Kraus TEC, Dahlgren RA, Zasoski RJ (2013) Tannins in nutrient dynamics of forest ecosystems - a review. Plant and Soil 256:4166. https://doi.org/10.1023/a:1026206511084

57. Sharma N, Sharma N, Dimple (2019) An evaluation study of different rot fungi for degradation of pine needles under solid state fermentation. Int J Curr Microbial App Sc 8:588-601. https://doi. org/10.20546/IJCMAS.2019.806.069

58. Vashi H, Iorhemen OT, Tay JH (2018) Degradation of industrial tannin and lignin from pulp mill effluent by aerobic granular sludge technology. J. Water Process Engin 26:38-45. https://doi.org/10. 1016/j.jwpe.2018.09.002

59. Bhat TK, Singh B, Sharma OP (1998) Microbial degradation of tannins - a current perspective. Biodegradation 9:343-357. https://doi.org/10.1023/A:1008397506963

60. Nierop KGJ, Verstraten JM (2006) Fate of tannins in Corsican pine litter. J. Chem. Ecol 32:2709-2719. https://doi.org/10.1007/ s10886-006-9194-9

Publisher's Note Springer Nature remains neutral with regard to jurisdictional claims in published maps and institutional affiliations. 